\title{
Tax Administration of VAT: Impact of Changes
}

\author{
O.L. Mikhaleva ${ }^{1, *}$, K.S. Pavlova ${ }^{1}$, V.S. Charikov ${ }^{1}$ and D.V. Aseev ${ }^{1}$ \\ *Corresponding author: mikhaleva2007@yandex.ru \\ ${ }^{1}$ Samara State University of Economics, Samara, Russia
}

\begin{abstract}
The relevance of the issue examined is stipulated by the results of the conducted study of the term "tax administration" and analysis of the impact of changes in tax administration of value added tax (VAT). The purpose of this study is to investigate the impact of changes in tax administration on VAT efficiency and collection rate. Within the context of digital economy, the state implements measures to digitize VAT tax control in order to reduce its own tax risks. The solution of this issue is the development of tax administration using digital technologies. A study has been conducted in order to assess impact of changes in the tax administration on VAT efficiency and collection rate.
\end{abstract}

Keywords: digital economy, tax administration, VAT, tax risks, automated control system, conscientious taxpayer.

\section{Introduction}

Digitization of the Russian economics pervades the field of taxation as well. As digital technologies are introduced, tax control can be performed on a whole new level. As a result, the load on tax inspectors is reduced, making it possible to pay more attention to the tax administration itself. Over the time of the existence of VAT in the Russian tax system, a certain calculated procedure for this tax has been developed, and tax administration mechanism was formed. It is obvious that VAT's dependency on tax deduction and refunding makes it vulnerable in terms of administration risks compared to other taxes.

The relevant changes are made in the Tax Code of the Russian Federation as response to the main challenges of the digital economy. The use of state-of-art technologies makes it possible to get closer to real-time VAT tax administration.

\section{Problem Statement}

There is no official definition of tax administration, though this notion is used in documents addressing taxation issues. Currently, there are various perspectives regarding the concept of "tax administration".

According to A.V. Bryzgalin, tax administration is the process of taxation management implemented by tax authorities and other authorities (tax administrations), authorized with powers towards taxpayers and levy payers [1].

According to I.A. Maiburov, tax administration is the process of taxation management implemented by tax authorities and other authorities (tax administrations), vested with certain powers towards taxpayers and levy payers [5]. The "tax administration" term, in broad sense, covers a wide range of activities and state tax system controls [6].

Michael Keen and Joel Slemrod set out a framework for analyzing optimal interventions by a tax administration, one that parallels and can be closely integrated with established frameworks for consideration of an optimal tax policy [4].

For proper functioning, the government requires funds which are obtained through tax revenue. VAT is one of the basic tax revenue sources of the budget of the Russian Federation. Currently, VAT is the main part of tax income in 136 countries and constitutes approximately $25 \%$ of global tax revenues [3].

International economics pays a lot of attention to issues of tax administration and challenging VAT issues. Iris Claus considers some practical implications of a variable VAT. Then, she develops a dynamic general equilibrium model in order to assess its benefit as a stabilization tool. A variable rate VAT would no longer be less distortionary than other taxes. It would distort between current and future consumption, i.e. savings and investment decisions, and hence raise the economic costs of taxation. A change in the interest rate affects savings and investment decisions within this period, whereas the variable VAT rate will be impacting the savings and investment decision over time. A variable VAT rate is therefore unlikely to act as a useful stabilization tool [2].

Pavel Semerád and Lucie Bartůn̆kova discuss the issue of value added tax control statement. Their aim is to assess, based on analysis of available information, this tax fraud control tool and to predict possible impact on tax authorities covered by category of small and medium companies (SMC), as well as impact on the revenue part of the national budget. Results show that, while such measure is beneficial for the tax authority, good faith entities suffer a financial load - particularly, by sanctions [9]. The main recent innovations on the improvement of VAT tax administration have revealed the necessity of analysis of the impact of these changes on efficiency of its quality and tax collection rate. 


\section{Research Questions}

The main questions of the study are the following:

- definition of the concept of "tax administration" and its role in ensuring revenues to the budget of taxes and fees;

- assessment of the current state of VAT tax administration and related issues;

- using digital technologies to improve the quality of tax control and improve the tax administration of VAT.

\section{Purpose of the Study}

The purpose of this study is to investigate the impact the problems of tax administration of VAT. As a result, assess the impact of changes in tax administration on the effectiveness of the quality and collection of this tax.

\section{Research Methods}

The various methods were used in the process of research. It is possible to carry to them: theoretical (dialectical logic, rational knowledge, etc.); diagnostic (diagnostic analysis of the condition and causes); empirical (description of the facts, measurement and generalization of research results).

\section{Findings}

The analysis of different approaches towards determination of tax administration showed that it can be understood as an activity of competent authorities focused on management processes in respect of taxes and fees.

The aim of the tax administration is to provide collection of taxes and fees to the budget with the optimal combination of tax regulation and tax control methods. Therefore, tax or levy administration can be considered to be an established control system for calculation and payment of a certain tax or levy.

One of advantage of VAT is that tax is collected at all stages of production cycle. It is believed that this tax cannot be avoided, as tax authorities are capable to find out the cost of acquired raw materials and selling price of the goods produced from these materials.

Despite the positive qualities of VAT, disputes with the tax authorities concerning calculation, application of tax deductions, and the good faith of counter parties often arise. It is rather difficult to assess the actual size of losses for the budget from application of VAT evasion or reimbursement schemes. The efficiency factor is used to assess quality of VAT administration in the international practice. It shows what fraction of the base (end use) is effectively taxed. An increase of coefficient indicates high quality of tax administration. VAT efficiency coefficient $=$ VAT revenues/VAT standard rate x Final consumption expenditure. VAT administration efficiency evaluation is made based on the Federal State Statistics Service of the RF as shown in Table 1.

Table 1. The dynamics of the coefficient of efficiency of VAT in the Russian Federation for 2013-2017

\begin{tabular}{|l|c|c|c|c|c|}
\hline \multicolumn{1}{|c|}{ Indicators } & $\mathbf{2 0 1 3}$ & $\mathbf{2 0 1 4}$ & $\mathbf{2 0 1 5}$ & $\mathbf{2 0 1 6}$ & $\mathbf{2 0 1 7}$ \\
\hline VAT receipts, trillion rub. & 1,9 & 2,2 & 2,4 & 2,7 & 3,1 \\
\hline $\begin{array}{l}\text { Final consumption } \\
\text { expenditure, trillion. rub. }\end{array}$ & 38,5 & 42 & 43,2 & 43,9 & 48 \\
\hline Tax rate VAT,\% & 18 & 18 & 18 & 18 & 18 \\
\hline Efficiency ratio & 0,27 & 0,29 & 0,31 & 0,34 & 0,36 \\
\hline
\end{tabular}

Source: compiled by the authors.

The analysis of the data received shows a low level of VAT efficiency coefficient (with the maximum equal to 1), but the increasing trend is evident. Further improved VAT collection can be achieved through the improvement of the quality of tax administration.

The quality of VAT tax administration can be also accessed by using tax collection rate, which is determined by ratio of the amount of VAT received by the budget to the amount of tax payable [8]. The coefficient value shows the effectiveness of implementation of the fiscal function of the tax.

Table 2 shows trends of VAT revenues and calculations in the RF for 2013-2017, making it possible to determine the tax collection rate for the same period. 
Table 2. Dynamics of receipts and VAT charges to the budget of the Russian Federation for 2013-2017

\begin{tabular}{|l|c|c|c|c|c|}
\hline \multicolumn{1}{|c|}{ Indicator } & $\mathbf{2 0 1 3}$ & $\mathbf{2 0 1 4}$ & $\mathbf{2 0 1 5}$ & $\mathbf{2 0 1 6}$ & $\mathbf{2 0 1 7}$ \\
\hline $\begin{array}{l}\text { Accrued payable, } \\
\text { mln. rub. }\end{array}$ & 1978956 & 2285668 & 2589229 & 2843777 & 3153815 \\
\hline $\begin{array}{l}\text { Received in the } \\
\text { budget, mln. rub. }\end{array}$ & 1868209 & 2181420 & 2448348 & 2657395 & 3069928 \\
\hline Collection rate, \% & 94,4 & 95,4 & 94,6 & 93,4 & 97,3 \\
\hline
\end{tabular}

Source: compiled by the authors.

The analysis of the received coefficient values shows that there are reserves for the increase of VAT collection rate by means of debt elimination. Therefore, VAT administration instruments need to be improved.

To improve this tax, the VAT taxation system is constantly being amended. The VAT control mechanism has been fundamentally rebuilt in recent years. It has begun to be implemented in fully automated way in the entire chain of value-added formation.

Since 2015, the taxpayers are obliged to submit VAT returns to tax authorities only in electronic form via telecommunication networks (TCN). The tax return includes data from purchase ledgers and sales ledgers. These changes have improved the level of control over VAT payment and reimbursement with an aim to prevent loss of budget funds.

Tax legislation of the RF provides an opportunity to the taxpayer to reduce the amount of VAT to the amount of tax deductions. A tax deduction is an amount of input VAT, which can be used by the payer to reduce the amount of the tax to be paid to the budget.

Payers have a right to VAT deduction if the following conditions are fulfilled at the same time (art. 171 of the Tax Code of the RF):

- $\quad$ acquired goods, works, services should be used in the activities subject to tax;

- $\quad$ acquired goods, works, services are registered (fulfilled, rendered);

- $\quad$ there is a tax invoice from the seller and correspondent primary documents.

There are also deductions that apply to specific situations: goods refunds, construction and assembly operations, for advance payment, in cases of price changes, etc. (Article 171 of the Tax Code).

The total amount of VAT deductible for 2017 in the Russian Federation amounted to 36,469,691 million rubles and increased by 624,972 million rubles as compared to 2016 .

In recent years, tax authorities have been increasingly using risk-oriented approach in their tax control activities. In order to increase the efficiency of tax control, including the justification of VAT reimbursement paid by the budget to the taxpayers, the Federal Tax Service of Russia has introduced an automated control system called ACS VAT-2.

Since 2015, ACS VAT-2 is used to analyze the data on tax invoices as declared in tax returns and searches for inconsistencies between invoices of different tax payers [7]. The purpose of this software package was to increase the budget revenue. Table 3 analyzes the trends of VAT revenue in the budget of the Russian Federation.

Table 3. Dynamics of VAT receipts in the budget of the Russian Federation for 2013-2017

\begin{tabular}{|c|c|c|}
\hline Period, year & $\begin{array}{c}\text { Received VAT, } \\
\text { million rubles }\end{array}$ & $\begin{array}{c}\text { The growth rate of VAT } \\
\text { receipts, \% }\end{array}$ \\
\hline 2013 & 1977041,1 & - \\
\hline 2014 & 2300821,9 & $16 \%$ \\
\hline 2015 & 2805209,23 & $21 \%$ \\
\hline 2016 & 3017179,03 & $8 \%$ \\
\hline 2017 & 3233413,6 & $7 \%$ \\
\hline
\end{tabular}

Source: compiled by the authors.

It can be seen from this analysis that the peak increase of VAT revenue was in 2015, when ACS VAT-2 was adopted. In the following two years, there was a steady increase in the revenues of this tax. In general, VAT revenues for 2017 increased by 1,244,739.9 million rubles compared to 2012.

ACS VAT-2 uses various risk criteria, including the tax burden, profitability, liabilities, information about the founders, etc. The system categorizes all VAT payers into 3 risk groups: high, medium, low. Low tax risk (pay VAT, do not interact with suspected empty shell companies, have proper resources to conduct their business). High tax risk (fail to pay VAT or pay it in the minimum amount, interact with suspected empty shell companies, lack proper resources to conduct their business). Medium tax risk (anything else that does not fall into the above categories).

This system facilitated in reduction of the period for conducting an office VAT return audit to 2 months, starting from July 1, 2017. This procedure is intended for good faith taxpayers.

A good faith taxpayer shall comply with the following criteria:

- uses legitimate ways to reduce the amount of taxes;

- pays full taxes on time;

- submits reports in a timely manner;

- promptly responds to inquiries of tax authorities;

- provides access to information for tax control.

In order to prevent possible complaints against improper diligence and integrity, taxpayers should take proper 
actions while establishing relations with contractors, such as: checking the counterparty using the services of the Federal Tax Service of Russia, asking the counterparty for a set of documents to demonstrate its legitimacy.

With the adoption of ACS VAT-2, the number of shell companies was reduced by more than two times, and the number of cases of outstanding VAT repayment (by companies with high tax risk) increased by about 15 times. According to the Federal Tax Service of Russia, the budget received an additional VAT revenue in the amount of 56 billion rubles within 2017 through the use of ACS VAT-2.

The adoption of this system contributed to the solution of many challenges in improving VAT administration. At the same time, despite all the positive aspects, there still is a number of problems requiring necessary action to be taken by the government.

For instance, one of these problems is the issue of VAT rate increasing to $20 \%$. Any change in VAT rate requires special attention. On the one hand, increased tax rate can result in an increase of the budget tax revenue. On the other hand, there may be an increase in the shadow economy due to the reluctance of businesses to pay higher taxes. As a result, there may be a decrease in investment attractiveness.

\section{Conclusion}

The conducted analysis confirms that the use of advanced technology in order to improve the quality of tax control contributed to the improvement of VAT administration. The measures taken to improve tax administration facilitated to the identification of dishonest taxpayers. All changes have had a positive effect on the efficiency of VAT administration.

The use of information technology not only reduces the tax risks of the state authorities, but also enables innovative ways for the development of tax administration due to access to a significant amount of taxpayer information.

\section{References}

1. A.V. Bryzgalin, Legal basis of tax administration. Economy and Law, 3, 3-17 (2007). [in Rus.].

2. I.A. Mayburov, Taxes and taxation. 5th ed. Moscow, Russia: Unity-dana (2012). [in Rus.].

3. O.L. Mikhaleva, D.V. Zabiyakin, VAT administration: Current status. In G.R. Khasaev \& S.I. Ashmarina (Eds.), Collection of articles of the $1^{\text {st }}$ Russian scientific-practical conference Russian science: Current research and development, (pp. 28-31). Samara, Russia: Samara State Economic University (2016). [in Rus.].

4. M. Keen, J. Slemrod, Optimal tax administration. Journal of Public Economics, Elsevier, 152(C), 133-142. DOI: 10.1016/j.jpubeco.2017.04.006 (2017).

5. L. Ebrill, M. Keen, J.-P. Bodin, V. Summers (Eds.), The modern VAT. Washington, DC: International Monetary Fund (IMF) (2001).

6. I. Claus, Is the value added tax a useful macroeconomic stabilization instrument? Economic Modelling, Elsevier 30(C), 366-374. DOI: 10.1016/j.econmod.2012.08.025 (2013).

7. P. Semerád, L. Bartůňkova, VAT control statement as a solution to tax evasion in the Czech Republic. Procedia Social and Behavioral Sciences, 220, 417-423. DOI: 10.1016/j.sbspro.2016.05.516 (2016).

8. M.A. Nazarov, S.A. Chekhovskikh, Problems of evaluating the effectiveness of tax administration. In G.R. Khasaev \& S.I. Ashmarina (Eds.), Collection of articles of the international scientific-practical conference Science of the 21 st Century: Current Trends, (pp. 401-405). Samara, Russia: Samara State Economic University (2016). [in Rus.].

9. M.V. Mishustin, Information and technical foundations of state tax administration. Moscow, Russia: Unity-dana (2005). [in Rus.]. 